\title{
ISOZYMES OF LACTIC DEHYDROGENASE IN HUMAN TISSUES *
}

\author{
By ELLIOT S. VESELL AND ALEXANDER G. BEARN
}

(From The Rockefeller Institute New York, N. Y.)

(Submitted for publication September 29, 1960; accepted November 3, 1960)

The heterogeneity of lactic dehydrogenase (LDH) activity in human serum and erythrocytes has been observed in several laboratories (1-7). If each of the electrophoretically-distinguishable enzymes in serum with LDH activity were derived from different tissues, in disease states involving a single organ the normal pattern of serum LDH activity would be altered according to the type of $\mathrm{LDH}$ released from the affected organ. This hypothesis was supported by analysis of sera from patients with myocardial infarction and leukemia (1-7). The results suggested that several tissues had characteristic electrophoretic distributions of lactic dehydrogenase activity. It was concluded that the patterns of serum LDH activity obtained by electrophoresis furnished more information regarding the site of pathology than did an examination of the LDH activity of whole serum (1-3). Furthermore, when several tissues were affected in a generalized disease process, as in hemorrhagic or endotoxic shock, it was found that all of the peaks of LDH activity in serum were elevated (8, 9 ), in contrast to the selective elevation of certain peaks in conditions involving individual tissues. The term isozyme was proposed by Markert and M $\varnothing$ ller to refer to the electrophoretically-distinguishable enzymes with similar substrate specificities (6). The present study demonstrates the heterogeneity of $\mathrm{LDH}$ activity in several human tissues and correlates the electrophoretic patterns of $\mathrm{LDH}$ activity obtained in tissues with those of sera in certain disease states.

\section{MATERIALS AND METHODS}

Four $\mathrm{g}$ of heart, of kidney, of liver and of skeletal muscle were obtained within 12 hours after the death of 8 patients from the following conditions: carcinoma of the cervix, bladder, breast, or kidney, brain tumor,

* These studies were supported in part by a grant-inaid, A-1542 (C3), from the United States Public Health Service, and aided by a grant from The National Foundation. diabetic gangrene of right foot, rheumatic heart disease and mitral stenosis, and rheumatic heart disease and aortic stenosis. No metastases to the liver, heart or kidney occurred in the cancer group. The tissues were washed thoroughly in cold normal saline to remove the majority of red cells and were rinsed in cold water to lyse any remaining erythrocytes. Homogenates were prepared in $10 \mathrm{ml}$ of barbital buffer, $\mathrm{pH} 8.6$, ionic strength 0.1 , using a mortar and pestle and then submitting the tissues to further grinding in a Potter-Elvehjem motor-driven tissue homogenizer. Centrifugation of these extracts for 40 minutes at $15,000 \mathrm{G}$ produced a supernatant fluid which was decanted and diluted with an equal volume of barbital buffer, $\mathrm{pH}$ 8.6. Four $\mathrm{ml}$ of the diluted supernatant was separated electrophoretically on a starch supporting medium in barbital buffer, $\mathrm{pH}$ 8.6, with an ionic strength of 0.1 . After electrophoresis at $4^{\circ} \mathrm{C}$ for 36 hours at $400 \mathrm{v}$ and $120 \mathrm{ma}$, each of the sections of the starch block was cut into 0.5 inch segments, the protein eluted with $5.0 \mathrm{ml}$ barbital buffer and its concentration determined (10). An aliquot from each eluate was then assayed spectrophotometrically for $\mathrm{LDH}$ activity (11). Between 85 and 98 per cent of the $\mathrm{LDH}$ activity of the homogenate was recovered from the block following electrophoresis. Each eluate was incubated for 20 minutes at room temperature with $0.2 \mathrm{ml}$ of $0.003 \mathrm{M}$ diphosphopyridine nucleotide reduced (DPNH) and $2.5 \mathrm{ml}$ of barbital buffer, $\mathrm{pH} 8.6$, ionic strength 0.1 . The mixture was transferred to a Beckman cuvet of 1 cm path length; $0.1 \mathrm{ml}$ of $0.001 \mathrm{M}$ sodium pyruvate was added, and the decrease in absorption at $340 \mathrm{~m} \mu$ was measured in the Beckman DU spectrophotometer. Readings were obtained every 30 seconds for 3 minutes. One unit of dehydrogenase activity was defined as a decrease in the optical density at $340 \mathrm{~m} \mu$ of 0.001 per minute.

In several experiments, a hemolysate prepared from human red cells (12) was fractionated electrophoretically and the eluates were assayed for LDH activity.

Human white cells were obtained from $40 \mathrm{ml}$ of heparinized blood by the method described by Hirsch and Church (13). The LDH activity was extracted from this purified preparation of leukocytes by freezing in acetone and dry ice, followed by rapid thawing. The white blood cell extract was separated electrophoretically and the eluates were assayed for LDH activity.

Serum $(5 \mathrm{ml}$ each) from a patient with hepatitis and from a healthy control were separated simultaneously on a starch block.

The $\mathrm{pH}$ optimum for each peak of $\mathrm{LDH}$ activity was determined. An aliquot from the tube containing the 
maximal LDH activity in each peak was removed and added to barbital buffers, varying in $\mathrm{pH}$ from 7.4 to 9.2 , all at 0.1 ionic strength. $\mathrm{LDH}$ activity was then reassayed as described above.

The Michaelis-Menten constants $(\mathrm{Km})$ of lactic dehydrogenase were determined for each of the 5 peaks of $\mathrm{LDH}$ activity. One-thousandfold variations in the final concentration of sodium lactate (from $1.6 \times 10^{-3}$ moles

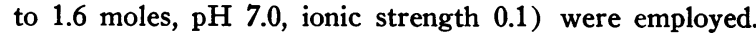
Diphosphopyridine nucleotide (DPN) was used $(0.3 \mathrm{ml}$ of a $0.05 \mathrm{M}$ solution adjusted to $\mathrm{pH} 7.5$ ) (14). Barbital buffer, $\mathrm{pH} 8.6$, ionic strength 0.1 , was added to an aliquot from the tubes with peak $\mathrm{LDH}$ activities. The final $\mathrm{pH}$ was 8.6 in a constant volume of $3.0 \mathrm{ml}$. The mixture was assayed for $\mathrm{LDH}$ activity and the $\mathrm{Km}$ calculated according to the method of Lineweaver and Burk (15).

\section{RESULTS}

Five electrophoretically-distinguishable peaks of $\mathrm{LDH}$ activity were observed in the homogenates of human tissues. According to the convention of earlier publications $(2-4)$ enumeration will be made from the slower to the more rapidly migrating peaks. Figure 1 relates the mobility of these activity peaks to the electrophoretic pattern of serum proteins. Peaks 1 and 2 migrated with the mobility of $\gamma$-globulin, peak 3 with the mobility of $\beta$-globulin, peak 4 with the mobility of $\alpha_{2}$-globulin and peak 5 with a mobility between $\alpha_{1}$-globulin and albumin. Serum from a patient with hepatitis exhibited all five activity peaks; normally, peak 1 was present only in trace amounts and peak 2 contained less of the total activity, as shown by the control serum in Figure 1. Not all five activity peaks appeared in each of the tissues. Liver exhibited five peaks, whereas kidney, red cells and white cells revealed four, and heart and skeletal muscle had three peaks. The percentage of the total LDH activity found in each peak was relatively constant, as indicated by the values in Table I. Furthermore,

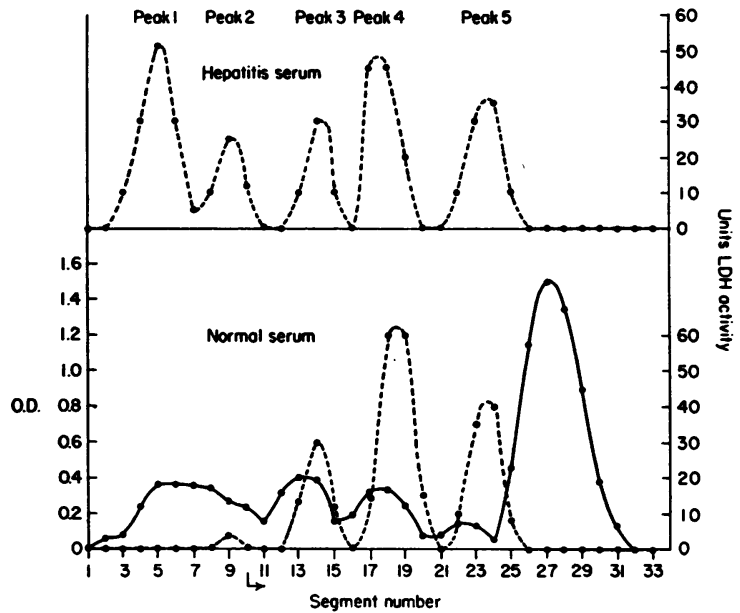

Fig. 1. Distribution of lactic Dehydrogenase aCTIVITY IN NORMAL HUMAN SERUM AND IN SERUM FROM A patient With hepatitis. The lower curves show the electrophoretic pattern of normal human serum in the solid line and the distribution of lactic dehydrogenase activity of the same serum in broken lines. The upper curve shows the LDH activity in the serum from a patient with hepatitis separated on the same starch block. Note the appearance of peak 1 in this serum and the increased activity in peak 2 , as compared with the normal serum below.

each tissue had a characteristic distribution of $\mathrm{LDH}$ activity. Most of the LDH activity in heart appeared in peak 5 with a smaller component in peak 4 , whereas in liver the majority of the activity was found in peaks 1 to 3 , and in skeletal muscle the largest portion of $\mathrm{LDH}$ activity was in peak 1. In kidney homogenate most of the $\mathrm{LDH}$ activity was divided between peaks 4 and 5 , and in leukocyte extract peak 4 contained the majority of the LDH activity (Table I). The mobility of each of the activity peaks in one tissue resembled the mobility of the corresponding peaks in other tissues, as shown in Figure 2. Figure 3 also illustrates the similarity in mobility of activity

TABLE I

Lactic dehydrogenase activity in fractions of human tissues with standard deviations

\begin{tabular}{|c|c|c|c|c|c|c|}
\hline \multirow[b]{2}{*}{ Tissue } & \multirow{2}{*}{$\begin{array}{l}\text { No. of } \\
\text { cases }\end{array}$} & \multicolumn{5}{|c|}{ Per cent total activity } \\
\hline & & Peak 1 & Peak 2 & Peak 3 & Peak 4 & Peak 5 \\
\hline $\begin{array}{l}\text { Heart } \\
\text { Kidney } \\
\text { Liver } \\
\text { Skeletal muscle } \\
\text { Hemolysate } \\
\text { White blood cells }\end{array}$ & $\begin{array}{l}8 \\
8 \\
8 \\
4 \\
5 \\
5\end{array}$ & $\begin{array}{l}37 \pm 9.6 \\
78 \pm 8.95\end{array}$ & $\begin{array}{r}2 \pm 2.9 \\
24 \pm 11.9 \\
17 \pm 8.6 \\
1 \pm 1.8 \\
6 \pm 3.6\end{array}$ & $\begin{array}{r}3 \pm 2.5 \\
11 \pm 8.1 \\
27 \pm 7.2 \\
5 \pm 4.2 \\
12 \pm 2.9 \\
33 \pm 6.1\end{array}$ & $\begin{array}{r}24 \pm 4.7 \\
45 \pm 5.2 \\
8 \pm 8.9 \\
44 \pm 4.3 \\
49 \pm 5.1\end{array}$ & $\begin{array}{r}73 \pm 5.6 \\
42 \pm 6.9 \\
4 \pm 6.6 \\
43 \pm 2.2 \\
12 \pm 3.6\end{array}$ \\
\hline
\end{tabular}




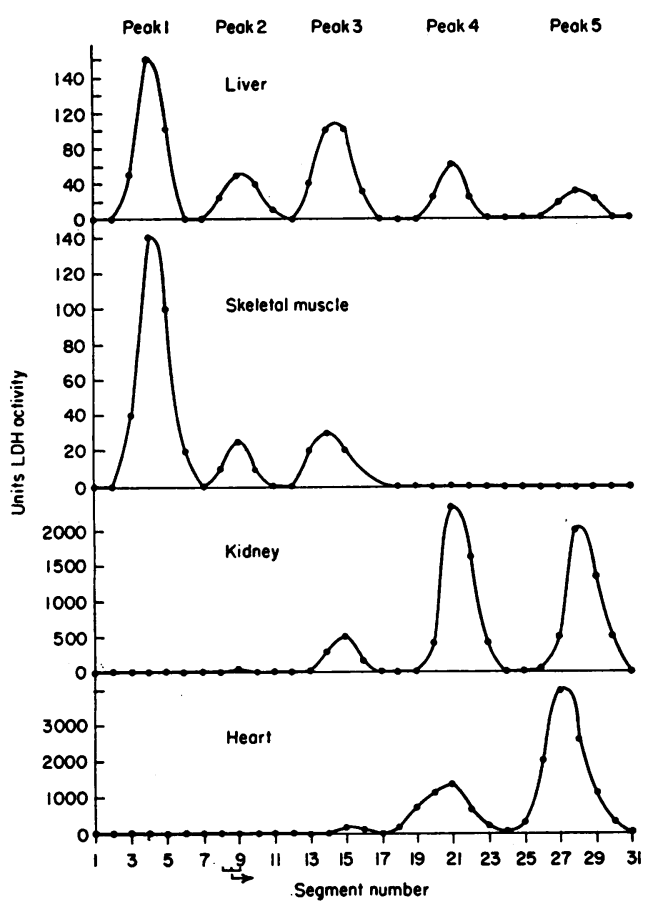

Fig. 2. Distribution of LACTIC Dehydrogenase ACTIVITY IN HOMOGENATES OF HUMAN HEART, LIVER, KIDNEY AND SKelETAL MUSCLE. These tissue homogenates were separated electrophoretically on the same starch block and are derived post mortem from a patient with carcinoma of the bladder.

peaks in one tissue to corresponding peaks in another tissue.

The $\mathrm{pH}$ optima of the 5 peaks of $\mathrm{LDH}$ activity were compared. Table II shows the close resem-

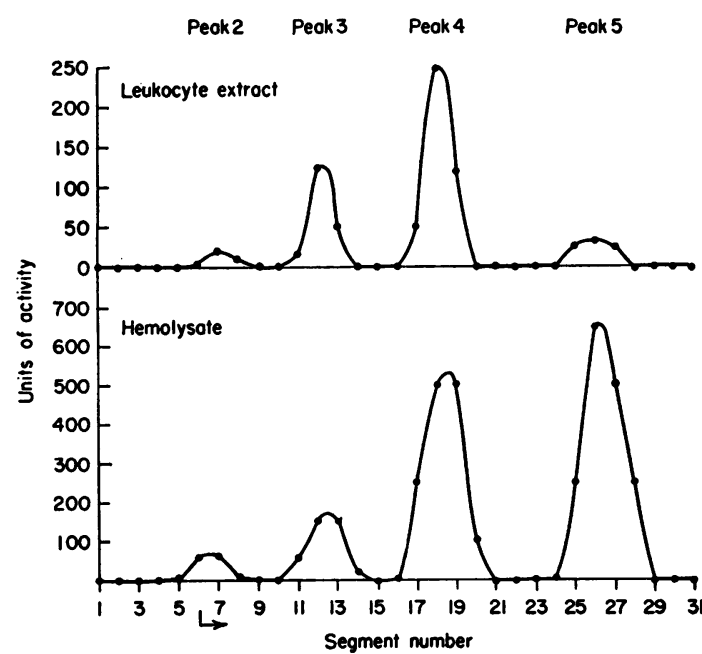

Fig. 3. Distribution of LACTIC DEH YDRogenase ACTIVITY IN NORMAL HUMAN HEMOLYSATE AND LEUKOCYTE EXTRACT.
TABLE II

pH optima of five peaks of LDH activity

\begin{tabular}{lccccc}
\hline & Peak 1 & Peak 2 & Peak 3 & Peak 4 & Peak 5 \\
\hline Heart & & & 8.0 & 8.1 & 8.2 \\
Hemolysate & & & 8.0 & 8.2 & 8.5 \\
Kidney & & & 7.8 & 8.1 & 8.3 \\
Liver & 8.3 & 8.3 & & & \\
Skeletal muscle & 8.2 & 8.2 & & & \\
\hline
\end{tabular}

TABLE III

Michaelis Menten constants (lactate) $\times 10^{-5}$ moles per $L$ for 5 peaks of LDH activity

\begin{tabular}{lccccc}
\hline & Peak 1 & Peak 2 & Peak 3 & Peak 4 & Peak 5 \\
\hline Heart & & & 1.9 & 1.5 & 1.2 \\
Kidney & & & 1.0 & 2.0 & 1.0 \\
Liver & 4.4 & 4.8 & & & \\
Skeletal muscle & 5.6 & 4.2 & & & \\
\hline
\end{tabular}

blance of these $\mathrm{pH}$ optima, which ranged from 7.8 to 8.5 . The differences in $\mathrm{pH}$ optima among the five peaks of $\mathrm{LDH}$ activity were not statistically significant.

The Michaelis-Menten constants $(\mathrm{Km})$ were calculated for the five activity peaks. The values obtained (Table III) revealed no significant differences among peaks 3,4 and 5 . The $\mathrm{Km}$ of peaks 1 and 2 (4.2 to $5.6 \times 10^{-5}$ moles) were

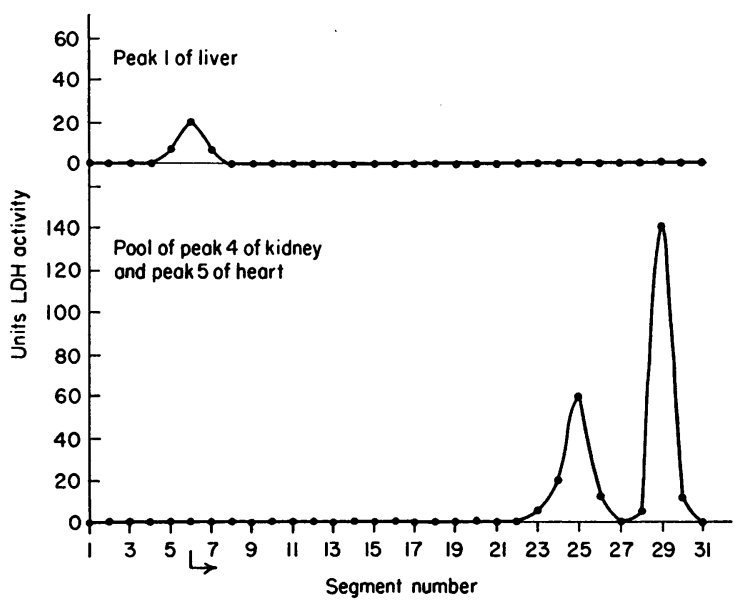

Fig. 4. The patterns obtained When peaks isoLATED FROM A STARCH BLOCK WERE RERUN ON A SECOND BLOCK. The upper curve represents peak 1 of liver homogenate rerun on a second block. The lower curve represents a rerun of a pool of peak 4 from kidney homogenate and of peak 5 from heart homogenate on a second block. Note that when these peaks are rerun they do not alter in mobility or give rise to peaks not present in the initial run. 
greater than the $\mathrm{Km}$ of peaks 3,4 and 5 (1.0 to $2.0 \times 10^{-5}$ moles).

Peak 5 from heart homogenate was pooled with peak 4 from kidney homogenate; the mixture was rerun on a second starch block under similar conditions, and the peaks had the same mobilities as in the starting material (Figure 4). Peak 1 from liver homogenate was rerun under identical conditions and no alterations in mobility from the starting material were observed (Figure 4).

\section{DISCUSSION}

Each of the homogenates of human tissue examined electrophoretically exhibited heterogeneity of LDH activity. Furthermore, each tissue had a constant number of activity peaks and a characteristic distribution of $\mathrm{LDH}$ activity in these peaks. The major portion of the $\mathrm{LDH}$ activity in heart homogenate was in peak 5 with a minor component in peak 4 . Liver homogenate had the highest activity in peaks 1, 2 and 3, whereas most of the LDH activity of leukocytes resided in peak 4 with minor components in peaks 3 and 5 . From analysis of alterations in the peaks of serum LDH activity in disease states, this type of distribution in tissues had been anticipated (1), from the hypothesis of enzyme release from damaged organs. In the sera of patients with myocardial infarction, a selective elevation of the LDH peaks with mobilities of $\alpha_{1}$ - and $\alpha_{2}$-globulins was observed (1-3), and the present study reveals that these are the locations of $\mathrm{LDH}$ activity in heart homogenate. The report of an elevated peak of LDH activity in the $\alpha_{2}$-globulin in certain leukemic sera (1) correlates with the observation that the majority of $\mathrm{LDH}$ activity in leukocytes is contained in this activity peak. The elevation of the LDH activity peak in the $\beta$-globulin and the appearance of a large activity peak in the $\gamma$-globulin in plasma from a patient with hepatitis are in harmony with the observation that the majority of LDH activity in liver homogenate resides in peaks with similar mobilities. Analagous to the appearance of a large LDH activity peak in serum during hepatitis is the appearance of additional peaks of leucine aminopeptidase activity in serum during liver disease (16). Both observations provide further support for the hypothesis that elevations in serum enzyme activity during several disease states are attributable in part to the liberation of enzymes from damaged organs.

Data of Hess (5) and Hill (17) are in accord with the reports of alterations in activity peaks of serum in cases of myocardial infarction and leukemia. However, Hill, employing curtain electrophoresis and a different method of obtaining leukocytes (17), localized the majority of LDH activity in leukocytes and erythrocytes in peak 3, whereas our data indicate that the majority of leukocyte LDH activity is contained in peak 4 and that peaks 4 and 5 contain most of the erythrocyte $\mathrm{LDH}$ activity. Wieme, utilizing agar gel electrophoresis, revealed 5 peaks of LDH activity in human serum (7). Peaks 1 and 2 were not constantly present and combined represented approximately 10 per cent of the total activity, the majority of the activity being distributed among peaks 3,4 and 5 . Wieme found that in patients with hepatitis, peaks 1 and 2 contained most of the serum LDH activity (7). This observation is confirmed in the present paper.

There are many examples of different molecular forms of enzymes in one organism and even in one tissue. Wieland and Pfleiderer observed several electrophoretically-distinguishable enzymes with $\mathrm{LDH}$ activity in several organs of the rat (18). The heterogeneity of pepsin (19), chymotrypsin (20), cytochrome C (21), ribonuclease (22), lysozyme (23), enolase (24), alkaline phosphatase (25), leucine aminopeptidase (16), ceruloplasmin (26), and cholinesterase (27) has been demonstrated. Emphasizing the similarities in substrate specificities of several enzymes previously shown to be heterogeneous, Markert and Møller proposed the useful term isozyme (6). They clearly distinguished isozymes, which exhibit similar substrate specificities and which usually resemble one another in several additional physicochemical characteristics, from different enzymes with broad substrate specificities which may overlap. Since comparison of the physicochemical factors in a group of electrophoretically-distinguishable enzymes which react with a common substrate is often difficult, caution must be exercised to avoid calling different enzymes with overlapping substrate specificities isozymes.

It appears unlikely that the differences in electrophoretic mobility of the $\mathrm{LDH}$ activity peaks are attributable to aggregation. Patterns similar 
to those obtained on a starch block, which separates proteins primarily by charge, are obtained on a starch gel (7), which separates protein according to molecular weight and shape as well as according to charge. Further evidence against aggregation is the monodispersion of whole serum LDH activity in the ultracentrifuge (28).

Studies of $\mathrm{pH}$ optima and $\mathrm{Km}$ are usually sufficient to distinguish between the active centers of different enzymes. The differences in $\mathrm{Km}$ of peaks 1 and 2 from peaks 3,4 and 5 suggest that the active centers of peaks 1 and 2 differ from those of peaks 3,4 and 5 . It is anticipated that further differences between each of the 5 isozymes will be established in the future. Previous studies showed that the inhibition behavior of peaks 3,4 and 5 of hemolysate was identical (2). The possibility arises that the active centers engaged in catalyzing the pyruvate-lactate reaction in the five $\mathrm{LDH}$ isozymes are similar. The variations in electrophoretic mobility of the five LDH isozymes may be explained by postulating structural differences in the enzyme other than at the active center. These differences might determine the location of an enzyme within the cell (29) and could function in binding the enzyme to a particular organelle within a specialized cell. It is conceivable that one gene controls the catalytic site and that other genes or the chemical environment of the cell determine the attachment of the enzyme (29). This hypothesis may be applicable to the species differences in insulin, ACTH and ribonuclease (30). Recent studies of polymorphism in pseudocholinesterase reveal that the mutant enzyme differs from the normal type in $\mathrm{pH}$ optima and in affinity for different substrates, and that the mutant enzyme fails to react with acetylcholine (31). Here, the gene probably determines the polypeptide chain of the catalytic active center of the enzyme.

During the preparation of this manuscript, two extensive studies were published on fractionation of $\mathrm{LDH}$ activity in mammalian tissues employing starch gel electrophoresis $(32,33)$. Although the gel technique yielded results similar to those of the present study, detailed quantitative comparison of the results is rendered difficult by trailing of LDH activity on the starch gel in some of the experiments (32).

\section{SUM MARY}

1. Heterogeneity of lactic dehydrogenase $(\mathrm{LDH})$ activity in the electrophoretically separated homogenates of human heart, kidney, liver, skeletal muscle, and extracts of leukocytes and erythrocytes is described. Five peaks of LDH activity were found in liver; four in kidney, leukocytes and erythrocytes, and three in heart and skeletal muscle. Each tissue exhibited a characteristic distribution of $\mathrm{LDH}$ activity: liver and skeletal muscle had the greatest activity in peaks 1, 2 and 3 ; whereas heart, hemolysate and kidney had most activity in peaks 4 and 5 . Leukocytes and serum showed highest activity in peak 3 .

2. The electrophoretic patterns of LDH activity in human tissues correlated with alterations in serum activity in disease states. In the serum from a case of hepatitis, a large peak of $\mathrm{LDH}$ activity is described which is present only in trace amounts in normal serum. This activity peak had the same mobility as the peak in liver with greatest LDH activity.

3. These observations suggest that assay of the LDH activity in the fractions of electrophoretically separated serum permits a greater specificity in localizing pathology than does assay of whole serum LDH activity.

4. Studies of Michaelis-Menten constants of the five peaks of $\mathrm{LDH}$ activity show peaks 1 and 2 to differ from peaks 3,4 and 5 . The possibility that the active centers of peaks 1 and 2 are different from the active centers of peaks 3,4 and 5 is discussed.

\section{REFERENCES}

1. Vesell, E. S., and Bearn, A. G. Localization of lactic acid dehydrogenase activity in serum fractions. Proc. Soc. exp. Biol. (N. Y.) 1957, 94, 96.

2. Vesell, E. S., and Bearn, A. G. Observations on the heterogeneity of malic and lactic dehydrogenase in human serum and red blood cells. J. clin. Invest. 1958, 37, 672.

3. Vesell, E. S., and Bearn, A. G. The heterogeneity of lactic and malic dehydrogenase. Ann. N. Y. Acad. Sci. 1958, 75, 286.

4. Sayre, F. W., and Hill, B. R. Fractionization of serum lactic dehydrogenase by salt concentration gradient elution and paper electrophoresis. Proc. Soc. exp. Biol. (N. Y.) 1957, 96, 695.

5. Hess, B. DPN-dependent enzymes in serum. Ann. N. Y. Acad. Sci. 1958, 75, 292. 
6. Markert, C. L., and Mфller, F. Multiple forms of enzymes: Tissue, ontogenetic, and species specific patterns. Proc. nat. Acad. Sci. (Wash.) 1959, 45, 753.

7. Wieme, R. J. Studies on Agar Gel Electrophoresis. Brussels, Arscia Uitgaven N.V., 1959.

8. Vesell, E. S., Feldman, M. P., and Frank, E. D. Serum lactic dehydrogenase activity in experimental hemorrhagic shock. Proc. Soc. exp. Biol. (N. Y.) 1959, 101, 644.

9. Vesell, E. S., Palmerio, C. F. P., and Frank, E. D. Serum lactic dehydrogenase activity in experimental endotoxic shock. Proc. Soc. exp. Biol. (N. Y.) 1960, 104, 403.

10. Kunkel, H. G. Zone electrophoresis in Methods of Biochemical Analysis, D. Glick, Ed. New York, Interscience Publishers, 1954, vol. 1, p. 141.

11. Wróblewski, F., and LaDue, J. S. Lactic dehydrogenase activity in blood. Proc. Soc. exp. Biol. (N. Y.) 1955, 90, 210.

12. Drabkin, D. L. Spectrophotometric studies. XIV. The crystallographic and optical properties of the hemoglobin of man in comparison with those of other species. J. biol. Chem. 1946, 164, 703.

13. Hirsch, J. G., and Church, A. B. Studies of phagocytosis of group A streptococci by polymorphonuclear leucocytes in vitro. J. exp. Med. 1960, 111, 309.

14. Wacker, W. E. C., Ulmer, D. D., and Vallee, B. L. Metalloenzymes and myocardial infarction. II. Malic and lactic dehydrogenase activities and zinc concentrations in serum. New Engl. J. Med. 1956, $255,449$.

15. Lineweaver, H., and Burk, D. The determination of enzyme dissociation constants. J. Amer. chem. Soc. $1934,56,658$.

16. Kowlessar, O. D., Haeffner, L. J., and Sleisenger, M. H. Localization of leucine aminopeptidase in serum and body fluids by starch gel electrophoresis. J. clin. Invest. 1960, 39, 671 .

17. Hill, B. R. Further studies of the fractionation of lactic dehydrogenase of blood. Ann. N. Y. Acad. Sci. 1958, 75, 304.

18. Wieland, T., and Pfleiderer, G. Nachweis der Heterogenität von Milchsäure-dehydrogenasen verschiedenen Ursprungs durch Trägerelektrophorese. Biochem. Z. 1957, 329, 112.
19. Desreux, V., and Herriott, R. M. Existence of several active components in crude pepsin preparations. Nature (Lond.) 1939, 144, 287.

20. Kunitz, M. Formation of new crystalline enzymes from chymotrypsin. Isolation of beta and gamma chymotrypsin. J. gen. Physiol. 1938, 22, 207.

21. Paléus, S., and Neilands, J. B. Preparation of cytochrome $\mathrm{C}$ with the aid of ion exchange resin. Acta chem. scand. 1950, 4, 1024.

22. Hirs, C. H. W., Stein, W. H., and Moore, S. Chromatography of proteins. Ribonuclease. J. Amer. chem. Soc. 1951, 73, 1893.

23. Tallan, H. H., and Stein, W. H. Studies on lysozyme. J. Amer. chem. Soc. 1951, 73, 2976.

24. Malmström, B. G. The purification of yeast enolase by zone electrophoresis and ion-exchange chromatography, and the existence of several active forms of the enzyme. Arch. Biochem. 1957, 70, 58.

25. Kowlessar, O. D., Pert, J. H., Haeffner, L. J., and Sleisenger, M. H. Localization of 5-nucleotidase and non-specific alkaline phosphatase by starch gel electrophoresis. Proc. Soc. exp. Biol. (N. Y.) 1959, 100, 191.

26. Broman, L. Separation and characterization of two coeruloplasmins from human serum. Nature (Lond.) 1959, 182, 1655.

27. Whittaker, V. P. Specificity, mode of action and distribution of cholinesterases. Physiol. Rev. 1951, $31,312$.

28. Hill, B. R., Kuff, E. L., and Hogeboom, G. H. Sedimentation behavior of serum lactic dehydrogenase. Proc. Soc. exp. Biol. (N. Y.) 1956, 92, 430.

29. Levinthal, C. in Genetics, H. E Sutton, Ed. New York, Josiah Macy Jr. Foundation, 1960, p. 190.

30. Anfinsen, C. B. The Molecular Basis of Evolution. New York, John Wiley \& Sons, 1959, p. 143.

31. Kalow, W., and Gunn, D. R. Some statistical data on atypical cholinesterase of human serum. Ann. hum. Genet. 1959, 23, 239.

32. Wróblewski, F., Ross, C., and Gregory, K. Isoenzymes and myocardial infarction. New Engl. J. Med. 1960, 263, 531.

33. Plagemann, P. G. W., Gregory, K. F., and Wróblewski, F. The electrophoretically distinct forms of mammalian lactic dehydrogenase. I. Distribution of lactic dehydrogenases in rabbit and human tissues. J. biol. Chem. 1960, 235, 2282. 